\title{
Multicenter comparison of three intraoperative hemoglobin trend monitoring methods
}

\author{
Richard L. Applegate II ${ }^{1,2}$ (1) $\cdot$ Patricia M. Applegate ${ }^{3} \cdot$ Maxime Cannesson $^{4,5} \cdot$ Prith Peiris $^{6} \cdot$ Beth L. Ladlie $^{6}$. \\ Klaus Torp ${ }^{6}$
}

Received: 3 October 2019 / Accepted: 20 November 2019 / Published online: 3 December 2019

(c) The Author(s) 2019

\begin{abstract}
Transfusion decisions are guided by clinical factors and measured hemoglobin $(\mathrm{Hb})$. Time required for blood sampling and analysis may cause $\mathrm{Hb}$ measurement to lag clinical conditions, thus continuous intraoperative $\mathrm{Hb}$ trend monitoring may provide useful information. This multicenter study was designed to compare three methods of determining intraoperative $\mathrm{Hb}$ changes (trend accuracy) to laboratory determined $\mathrm{Hb}$ changes. Adult surgical patients with planned arterial catheterization were studied. With each blood gas analysis performed, pulse cooximetry hemoglobin ( $\mathrm{SpHb}$ ) was recorded, and arterial blood $\mathrm{Hb}$ was measured by hematology $(\mathrm{tHb})$, arterial blood gas cooximetry (ABGHb), and point of care (aHQHb) analyzers. $\mathrm{Hb}$ change was calculated and trend accuracy assessed by modified Bland-Altman analysis. Secondary measures included $\mathrm{Hb}$ measurement change direction agreement. Trend accuracy mean bias (95\% limits of agreement; $\mathrm{g} / \mathrm{dl}$ ) for SpHb was 0.10 ( -1.14 to 1.35 ); for $\mathrm{ABGHb}$ was -0.02 ( -1.06 to 1.02$)$; and for $\mathrm{aHQHb}$ was 0.003 ( -0.95 to 0.95$)$. Changes more than $\pm 0.5 \mathrm{~g} / \mathrm{dl}$ agreed with $\mathrm{tHb}$ changes more than $\pm 0.25 \mathrm{~g} / \mathrm{dl}$ in $94.2 \%$ (88.9-97.0\%) SpHb changes, 98.9\% (96.1-99.7\%) ABGHb changes and 99.0\% (96.4-99.7\%) aHQHb changes. Sequential changes in SpHb, ABGHb and aHQHb exceeding $\pm 0.5 \mathrm{~g} / \mathrm{dl}$ have similar agreement to the direction but not necessarily the magnitude of sequential $\mathrm{tHb}$ change. While $\mathrm{Hb}$ blood tests should continue to be used to inform transfusion decisions, intraoperative continuous noninvasive SpHb decreases more than $-0.5 \mathrm{~g} / \mathrm{dl}$ could be a good indicator of the need to measure tHb.
\end{abstract}

Keywords Hemoglobin $\cdot$ Point of care tests $\cdot$ Noninvasive measurement $\cdot$ Intraoperative monitoring

Richard L. Applegate II

rapplegate@ucdavis.edu

1 Department of Anesthesiology, Loma Linda University, Loma Linda, CA, USA

2 Present Address: Department of Anesthesiology and Pain Medicine, University of California Davis, Sacramento, CA, USA

3 Department of Cardiology, University of California, Davis, Sacramento, CA, USA

4 Department of Anesthesiology and Perioperative Care, University of California Irvine, Irvine, CA, USA

5 Present Address: Department of Anesthesiology and Perioperative Care, University of California Los Angeles, Los Angeles, CA, USA

6 Department of Anesthesiology, Mayo Clinic in Florida, Jacksonville, FL, USA

\section{Introduction}

Hemoglobin $(\mathrm{Hb})$ measurement informs patient-specific perioperative transfusion decisions within the context of symptoms, comorbid conditions, surgical procedure, observed bleeding and hemodynamic performance [1, 2]. Hb measurement is a key component in many parts of patient blood management bundles [3], and is recommended between transfused red blood cell units if patient stability allows [4].

$\mathrm{Hb}$ measurement may be performed using clinical laboratory hematology $(\mathrm{tHb}$; closest to the cyanmethemoglobin standard [5]), arterial blood gas cooximetry (ABGHb), or point of care $\mathrm{Hb}$ analyzers. However, the time needed for blood sampling and analysis can cause $\mathrm{Hb}$ measurement to lag clinical situations. In surgical settings in which blood loss may not be apparent or be difficult to estimate, continuous rather than intermittent $\mathrm{Hb}$ monitoring could provide earlier warning of decreasing $\mathrm{Hb}$. 
Multiwave pulse cooximetry noninvasively determines total hemoglobin $(\mathrm{SpHb})$. $\mathrm{SpHb}$ has been tested in volunteers [6] and in a wide range of clinical settings [7]. Prior reports indicated wide limits of agreement between $\mathrm{SpHb}$ and $\mathrm{tHb}$ that suggest caution when using $\mathrm{SpHb}$ alone to guide transfusion decisions [7, 8]. However, it is possible that $\mathrm{SpHb}$ changes could provide useful information if the direction of $\mathrm{SpHb}$ change accurately reflects the direction of $\mathrm{tHb}$ change (trend). We defined trend accuracy as agreement of sequential changes in $\mathrm{SpHb}, \mathrm{ABGHb}$, or point of care $\mathrm{Hb}$ with sequential $\mathrm{tHb}$ changes. The aim of this multicenter study was to evaluate trend accuracy of three monitoring methods in patients undergoing surgery.

\section{Methods and materials}

This collaborative prospective convenience sample observational study received Institutional Review Board approval at each of three USA academic medical centers prior to study initiation: Loma Linda University (LLU), Loma Linda, CA; Mayo Clinic in Florida (MCF), Jacksonville, FL; and University of California Irvine (UCI), Irvine, CA. Patient consent was obtained according to local IRB determination at each site. All study procedures were performed in accordance with the ethical standards of the institutional and research committees and with the 1964 Helsinki declaration and its later amendments or comparable ethical standards. This manuscript adheres to applicable STARD guidelines.

Adult patients were eligible for study participation if scheduled to undergo non-cardiac surgery in which arterial catheterization and expected repeated intraoperative blood gas analyzes were planned as part of patient care. Patients were excluded if pregnant or for skin abnormalities at the planned application site that would interfere with pulse oximetry (burns, scar tissue, nail polish, or infection). Attending anesthesiologists had discretion over anesthesia management, fluid administration and transfusion decisions, which were based on clinical settings (surgical considerations, ongoing bleeding, hemodynamic condition and/or any patient comorbid conditions) and institutional guidelines, which were in keeping with published guidelines $[9,10]$.

Multiwave disposable pulse cooximetry finger sensors (R125, Radical-7, Revision K, Masimo, Irvine, CA) were placed on the ring finger on the side of arterial cannulation with data continuously collected to computer. Oximeters were set to arterial mode to align with the source of blood samples. The $\mathrm{SpHb}$ algorithm continuously evaluates up to $6 \mathrm{~min}$ of data to calculate the displayed value. Whenever arterial blood gas analysis was performed, $\mathrm{SpHb}$ displayed at the time arterial blood was drawn was recorded, and arterial blood samples were obtained in appropriate collection tubes. Blood sample analysis was completed within
10 min. Each blood sample was analyzed twice using the same analyzer for $\mathrm{tHb}, \mathrm{ABGHb}$ and $\mathrm{aHQHb}$ using:

- Clinical Laboratory hematology analyzer $H b(t H b$; LLU-Sysmex XE5000, Sysmex America Inc., Lincolnshire, IL, USA; MCF-Sysmex XE5000, Sysmex America Inc., Lincolnshire, IL, USA or Coulter AcTdiff, Beckman Coulter, Indianapolis, IN, USA. UCICoulter LH 750 Hematology Analyzer, Beckman Coulter, Brea, CA, USA)

- Arterial blood gas cooximetry Hb (ABGHb; LLURadiometer ABL800; Radiometer, Copenhagen, Denmark. MCF-CCX or PhOX, Nova Biomedical, Waltham, MA, USA; UCI-Siemens RAPIDLab 1265, Siemens Healthcare Diagnostics, NY, USA)

- Point of care Hb using arterial blood (aHQHb; not capillary or finger stick samples; HemoCue HB 301, HemoCue America, Brea, CA, USA)

\subsection{Statistical methods}

The primary outcome measure was trend accuracy using modified Bland-Altman analysis of difference between changes in $\mathrm{SpHb}, \mathrm{ABGHb}$ or $\mathrm{aHQHb}$ and $\mathrm{tHb}$ changes to $\mathrm{tHb}$ changes as the measurement standard, to obtain bias and 95\% limits of agreement between trends in $\mathrm{SpHb}$, $\mathrm{ABGHb}$, or $\mathrm{aHQHb}$ and $\mathrm{tHb}$ trend. Trends were defined as sequential change in $\mathrm{Hb}$ using results of the first analysis performed on each blood sample: Hb sample 2- $\mathrm{Hb}$ sample 1 ; Hb sample $3-\mathrm{Hb}$ sample 2 ; etc. We included in analysis only samples for which all measures were available for trend calculations and did not exclude or separately analyze $\mathrm{SpHb}$ in low perfusion states.

Power and sample size calculation: A prior study of patients undergoing similar procedures [11] reported a median of 4 (up to 9) blood samples allowing an average of 3 trend calculations per patient. The mean bias of $\mathrm{SpHb}$ to $\mathrm{tHb}$ reported in prior studies in which the intended hematology analyzers were used [7] ranged from -0.53 to 1.22 , with standard deviation averaging 1.055 . Using that standard deviation, setting alpha to 0.05 and power to 0.8 , a sample size of 135 patients would be needed to estimate the precision of the $95 \%$ confidence interval of the difference among the 3 methods within $0.2 \mathrm{~g} / \mathrm{dl}$ This is a conservative estimate of our true precision because patients would have repeated blood draws. Power analyses were performed using SAS 9.4 (SAS Institute, Cary, North Carolina, USA); statistical analyses were performed using JMP Pro version 13.2.0 (SAS Institute, Cary, North Carolina, USA) and Prism 8.1.0 (GraphPad Software, San Diego, California, USA). 


\section{Secondary outcome measures}

\subsection{Hb accuracy}

Calculated $\mathrm{Hb}$ change could be impacted by $\mathrm{Hb}$ measurement accuracy. Accuracy of $\mathrm{SpHb}, \mathrm{ABGHb}$ or aHQHb compared to $\mathrm{tHb}$ was evaluated by Bland-Altman analysis to determine bias and $95 \%$ limits of agreement. $\mathrm{Hb}$ measurement results were compared to clinically acceptable error as previously recommended [12].

\section{2 $\mathrm{Hb}$ measurement repeatability}

Results of the 2 analyses performed on each blood sample were compared by Bland-Altman analysis to find bias and 95\% limits of agreement for $\mathrm{tHb}, \mathrm{ABGHb}$ and $\mathrm{aHQHb}$.

\subsection{Agreement of change direction}

The $95 \%$ limits of agreement obtained from $\mathrm{Hb}$ measurement repeatability analysis were used to define exclusion zones for change direction agreement analysis. Change direction agreement was assessed overall and for samples with $\mathrm{tHb}<9.0 \mathrm{~g} / \mathrm{dl}$. This was reported as \% agreement; 95\% confidence interval.

\section{Results}

Each center enrolled independently with one-hundred thirty-five patients studied (Loma Linda University $n=51$; Mayo Clinic in Florida $n=58$; University of California Irvine $n=26$ ). On average patients had 4 samples obtained, ranging from 2 to 13 . A total of 568 blood gas samples were drawn from these patients. Of these, $5(0.88 \%)$ samples were missing a blood gas analysis result, $5(0.88 \%)$ were missing $\mathrm{SpHb}$ and 7 (1.23\%) had automated data collection errors, leaving 551 samples in which all measurements were available providing 416 changes to calculate trends for comparisons. Patient and procedure characteristics are shown in Table 1.

\subsection{Trend accuracy}

Modified Bland-Altman analysis showed small bias with slightly wider limits of agreement for $\mathrm{SpHb}$ trends compared to $\mathrm{ABGHb}$ or aHQHb trends (Fig. 1). Mean bias (limits of agreement $\mathrm{g} / \mathrm{dl}$ ) for $\mathrm{SpHb}$ was $0.10(-1.14$ to
1.35); for $\mathrm{ABGHb}$ was -0.02 (- 1.06 to 1.02 ); and for aHQHb was 0.003 ( -0.95 to 0.95$)$.

\section{2 $\mathrm{Hb}$ accuracy}

Compared to $\mathrm{tHb}$, mean bias (95\% limits of agreement) for $\mathrm{SpHb}$ was 0.24 (-2.05 to 2.53) $\mathrm{g} / \mathrm{dl}$; for $\mathrm{ABGHb}$ was -0.36 $(-1.47$ to 0.78$) \mathrm{g} / \mathrm{dl}$; and for $\mathrm{aHQHb}$ was -0.43 ( -1.46 to $0.60) \mathrm{g} / \mathrm{dl}$. Hb accuracy is plotted against clinically acceptable error $[12,13]$ in Fig. 2. None of the results were in the zone that has been proposed to potentially expose patients to larger risks [13].

\subsection{Measurement repeatability}

Bias (95\% limits of agreement) of results from the 2 analyses of each blood sample for tHb was $0.0055(-0.25$ to $0.26) \mathrm{g} / \mathrm{dl}$; for $\mathrm{ABGHb}$ was -0.032 ( -0.61 to 0.54$) \mathrm{g} / \mathrm{dl}$; and for $\mathrm{aHQHb}$ was $-0.0004(-0.62$ to 0.61$) \mathrm{g} / \mathrm{dl}$. These limits of agreement were used to set exclusion zones for comparing change direction agreement. A tHb change more than $\pm 0.25 \mathrm{~g} / \mathrm{dl}$ was considered an increase or decrease, while a change more than $\pm 0.5 \mathrm{~g} / \mathrm{dl}$ was considered an increase or decrease for $\mathrm{SpHb}, \mathrm{ABGHb}$ and $\mathrm{aHQHb}$.

\subsection{Agreement in change direction}

Using the defined exclusion zones, change direction agreed in 129 of $137 \mathrm{SpHb}$ changes (94.2\%; 88.9-97.0\%); 179 of 181 ABGHb changes (98.9\%; 96.1-99.7\%); and in 195 of $197 \mathrm{aHQHb}$ changes $(99.0 \%$; 96.4-99.7\%). Table 2 details change direction agreement for increases and decreases. Four quadrant plots using the defined exclusion zones are shown in Fig. 3. In all samples when $\mathrm{SpHb}, \mathrm{ABGHb}$ or $\mathrm{aHQHb}$ increased but $\mathrm{tHb}$ decreased the decreases in $\mathrm{tHb}$ were smaller than $-1 \mathrm{~g} / \mathrm{dl}$. For $\mathrm{tHb}<9.0 \mathrm{~g} / \mathrm{dl}$ changes in $\mathrm{SpHb}, \mathrm{ABGHb}$ or aHQHb more than $\pm 0.5 \mathrm{~g} / \mathrm{dl}$ agreed with tHb change direction in all but 3 instances (Fig. 4). Most samples in which $\mathrm{SpHb}, \mathrm{ABGHb}$ or $\mathrm{aHQHb}$ change was not more than $\pm 0.5 \mathrm{~g} / \mathrm{dl}$ were associated with $\mathrm{tHb}$ changes within $\pm 0.25 \mathrm{~g} / \mathrm{dl}$. However, when $\mathrm{tHb}$ was $<9.0 \mathrm{~g} / \mathrm{dl}$, one $\mathrm{ABGHb}$ and $3 \mathrm{SpHb}$ changes not more than $\pm 0.5 \mathrm{~g} / \mathrm{dl}$ had an associated $\mathrm{tHb}$ decrease more than $-1 \mathrm{~g} / \mathrm{dl}$.

\section{Discussion}

Intraoperative $\mathrm{Hb}$ trend accuracy limits of agreement were approximately $\pm 1 \mathrm{~g} / \mathrm{dl}$ for $\mathrm{ABGHb}$ and $\mathrm{aHQHb}$ and slightly larger for $\mathrm{SpHb}$ trends. Considering the $95 \%$ confidence intervals for agreement in change direction overlapped, our findings suggest that changes more than $\pm 0.5 \mathrm{~g} / \mathrm{dl}$ in $\mathrm{SpHb}$, $\mathrm{ABGHb}$ and $\mathrm{aHQHb}$ provide similar information regarding 
Table 1 Patient characteristics

\begin{tabular}{|c|c|c|c|c|}
\hline Patient characteristics & $\begin{array}{l}\text { All } \\
\mathrm{N}=135\end{array}$ & $\begin{array}{l}\mathrm{LLU} \\
\mathrm{N}=50\end{array}$ & $\begin{array}{l}\mathrm{MCF} \\
\mathrm{N}=59\end{array}$ & $\begin{array}{l}\text { UCI } \\
\mathrm{N}=26\end{array}$ \\
\hline \multicolumn{5}{|l|}{ Sex \# (\%) } \\
\hline Female & $70(51.9 \%)$ & $29(58.0 \%)$ & $26(44.1 \%)$ & $15(51.9 \%)$ \\
\hline Male & $65(48.1 \%)$ & $21(42.0 \%)$ & $33(55.9 \%)$ & $11(42.3 \%)$ \\
\hline Age years & $\begin{array}{l}61 \\
{[50-69]}\end{array}$ & $\begin{array}{l}58.5 \\
{[44.5-68.5]}\end{array}$ & $\begin{array}{l}63 \\
{[54-70]}\end{array}$ & $\begin{array}{l}58.5 \\
{[47.8-68.3]}\end{array}$ \\
\hline Weight kg & $\begin{array}{l}79.3 \\
{[66.1-96.2]}\end{array}$ & $\begin{array}{l}79.6 \\
{[64.9-98.9]}\end{array}$ & $\begin{array}{l}79.3 \\
{[66.6-92.6]}\end{array}$ & $\begin{array}{l}76.9 \\
{[64.6-96.4]}\end{array}$ \\
\hline Body mass index $\mathrm{kg} \mathrm{m}^{-2}$ & $\begin{array}{l}28.0 \\
{[24.0-32.7]}\end{array}$ & $28.0[24.5-35.0]$ & $28.1[23.8-29.9]$ & $27.9[22.7-33.2]$ \\
\hline Number of samples per patient & 4 & 4 & 4 & 4 \\
\hline Range & $\begin{array}{l}{[3-5]} \\
2-13\end{array}$ & $\begin{array}{l}{[3-5]} \\
2-6\end{array}$ & $\begin{array}{l}{[2-6]} \\
2-13\end{array}$ & $\begin{array}{l}{[4-4]} \\
2-4\end{array}$ \\
\hline $\begin{array}{l}\text { 1st intraoperative hemoglobin } \mathrm{g} / \mathrm{dl} \\
\text { Range }\end{array}$ & $\begin{array}{l}10.8 \\
{[9.1-11.9]} \\
5.9-14.7\end{array}$ & $\begin{array}{l}10.8 \\
{[9.3-11.9]} \\
5.9-14.7\end{array}$ & $\begin{array}{l}10.1 \\
{[8.6-11.7]} \\
6.8-13.8\end{array}$ & $\begin{array}{l}11.7^{\mathrm{a}} \\
{[10.3-12.9]} \\
9.1-13.8\end{array}$ \\
\hline $\begin{array}{l}\text { Intraoperative hemoglobin } \mathrm{g} / \mathrm{dl} \\
\text { Range }\end{array}$ & $\begin{array}{l}10.1 \\
{[8.9-11.5]} \\
4.9-14.7\end{array}$ & $\begin{array}{l}10.0 \\
{[8.7-11.3]} \\
4.9-14.7\end{array}$ & $\begin{array}{l}9.5 \\
{[8.6-11.0]} \\
5.9-14.1\end{array}$ & $\begin{array}{l}11.5 \\
{[10.3-12.5]} \\
8.4-14.3^{\mathrm{b}}\end{array}$ \\
\hline $\begin{array}{l}\text { Sequential change in laboratory } \\
\text { hemoglobin } \mathrm{g} / \mathrm{dl} \\
\text { Range }\end{array}$ & $\begin{array}{l}-0.1 \\
{[-0.6 \text { to } 0.4]} \\
-5.0 \text { to } 3.7\end{array}$ & $\begin{array}{l}0.3 \\
{[-0.8 \text { to } 0.3]} \\
-5.0 \text { to } 3.2^{\mathrm{d}}\end{array}$ & $\begin{array}{l}0 \\
{[-0.7 \text { to } 0.5]} \\
-3.3 \text { to } 3.7\end{array}$ & $\begin{array}{l}0 \\
{[-0.2 \text { to } 0.3]} \\
-3.3 \text { to } 0.9\end{array}$ \\
\hline Duration of monitoring minutes & $\begin{array}{l}302 \\
{[181-390]}\end{array}$ & $\begin{array}{l}335 \\
{[257-386]}\end{array}$ & $\begin{array}{l}354 \\
{[266-437]}\end{array}$ & $\begin{array}{l}88^{\mathrm{c}} \\
{[79-101]}\end{array}$ \\
\hline \multicolumn{5}{|l|}{ Surgical procedure type \# } \\
\hline Major abdominal & 58 & 19 & 26 & 13 \\
\hline Liver resection or transplant & 25 & 3 & 17 & 5 \\
\hline Major orthopedic & 16 & 8 & 5 & 23 \\
\hline Major urologic & 16 & 3 & 11 & 2 \\
\hline Major gynecologic & 12 & 11 & 0 & 1 \\
\hline Major vascular & 6 & 6 & 0 & 0 \\
\hline Major neurosurgical & 2 & 0 & 0 & 2 \\
\hline
\end{tabular}

Characteristics of patients undergoing surgery with arterial catheterization at one of 3 academic medical centers: $L L U$ Loma Linda University; MCF Mayo Clinic in Florida; UCI University of California Irvine. Results are median [25th to 75th percentile] except sex and procedure type which are number (\%)

${ }^{a}$ First intraoperative hemoglobin higher at UCI than LLU (Hodges Lehman difference 0.9; 0.1-0.8 g/dl $\mathrm{p}=0.03$ ) and MCF (Hodges Lehman difference 1.3; 0.5-2.2 $\mathrm{g} / \mathrm{dl} \mathrm{p}=0.003$ )

${ }^{\mathrm{b}}$ Intraoperative hemoglobin higher at UCI than LLU (Hodges Lehman difference 1.4; $1.0-1.8 \mathrm{~g} / \mathrm{dl}$ ) and MCF (Hodges Lehman difference 1.7; 1.3-2.1 g/dl) both $\mathrm{p}<0.0001$

${ }^{\mathrm{c}}$ Duration of monitoring less at UCI than LLU (Hodges Lehman difference $-237 ;-268$ to $-201 \mathrm{~min}$ ) and MCF (Hodges Lehman difference $-264 ;-298$ to -225 min) both $\mathrm{p}<0.0001$

${ }^{\mathrm{d} S e q u e n t i a l}$ change more negative at LLU than MCF (Hodges Lehman L difference $-0.2 ;-0.4$ to $0 \mathrm{~g} / \mathrm{dl}$; $\mathrm{p}=0.04$ ) and UCI (Hodges Lehman difference $-0.3 ;-0.4$ to $-0.1 \mathrm{~g} / \mathrm{dl} ; \mathrm{p}=0.006$ )

the direction of intraoperative tHb change, but not necessarily the magnitude of that change. The impact of trend accuracy on transfusion decision-making is more significant when $\mathrm{tHb}$ is less than $9.0 \mathrm{~g} / \mathrm{dl}$ as current guidelines suggest that red blood cell transfusion may be reasonable [14] for $\mathrm{tHb}<8.0 \mathrm{~g} / \mathrm{dl}$, but usually unnecessary [9] for $\mathrm{tHb}>10.0 \mathrm{~g} /$ dl. Analysis of change direction agreement suggests that if continuous $\mathrm{SpHb}$ is $<9 \mathrm{~g} / \mathrm{dl}$ then a decrease more than $-0.5 \mathrm{~g} / \mathrm{dl}$ could be a good indication to obtain a blood sample for $\mathrm{tHb}$ measurement.
Repeatability analysis demonstrated limits of agreement that have implications for $\mathrm{Hb}$ accuracy and trend monitoring studies. The exclusion zones we defined based on $95 \%$ limits of agreement for ABGHb and aHQHB suggest that in our patients, a change up to $\pm 0.5 \mathrm{~g} / \mathrm{dl}$ may not reflect a real change in circulating hemoglobin measured by $\mathrm{tHb}$. Similarly, reported $\mathrm{tHb}$ changes of $\pm 0.25 \mathrm{~g} / \mathrm{dl}$ may not represent real changes in circulating $\mathrm{Hb}$. Our findings support use of an exclusion zone when comparing $\mathrm{Hb}$ analyzer trend performance and highlight the need to provide specific 
Fig. 1 Modified Bland-Altman analysis of trend accuracy comparing 416 sequential changes in laboratory hematology analyzer hemoglobin ( $\mathrm{tHb}$ ) to the difference between $\mathrm{tHb}$ changes and paired sequential changes in top panel: pulse cooximetry hemoglobin $(\mathrm{SpHb})$; middle panel: arterial blood gas cooximetry hemoglobin (ABGHb) and bottom panel: Hemocue point of care hemoglobin using arterial blood (aHQHb). Horizontal dotted lines indicate $95 \%$ limits of agreement $( \pm 1.96 \mathrm{SD})$
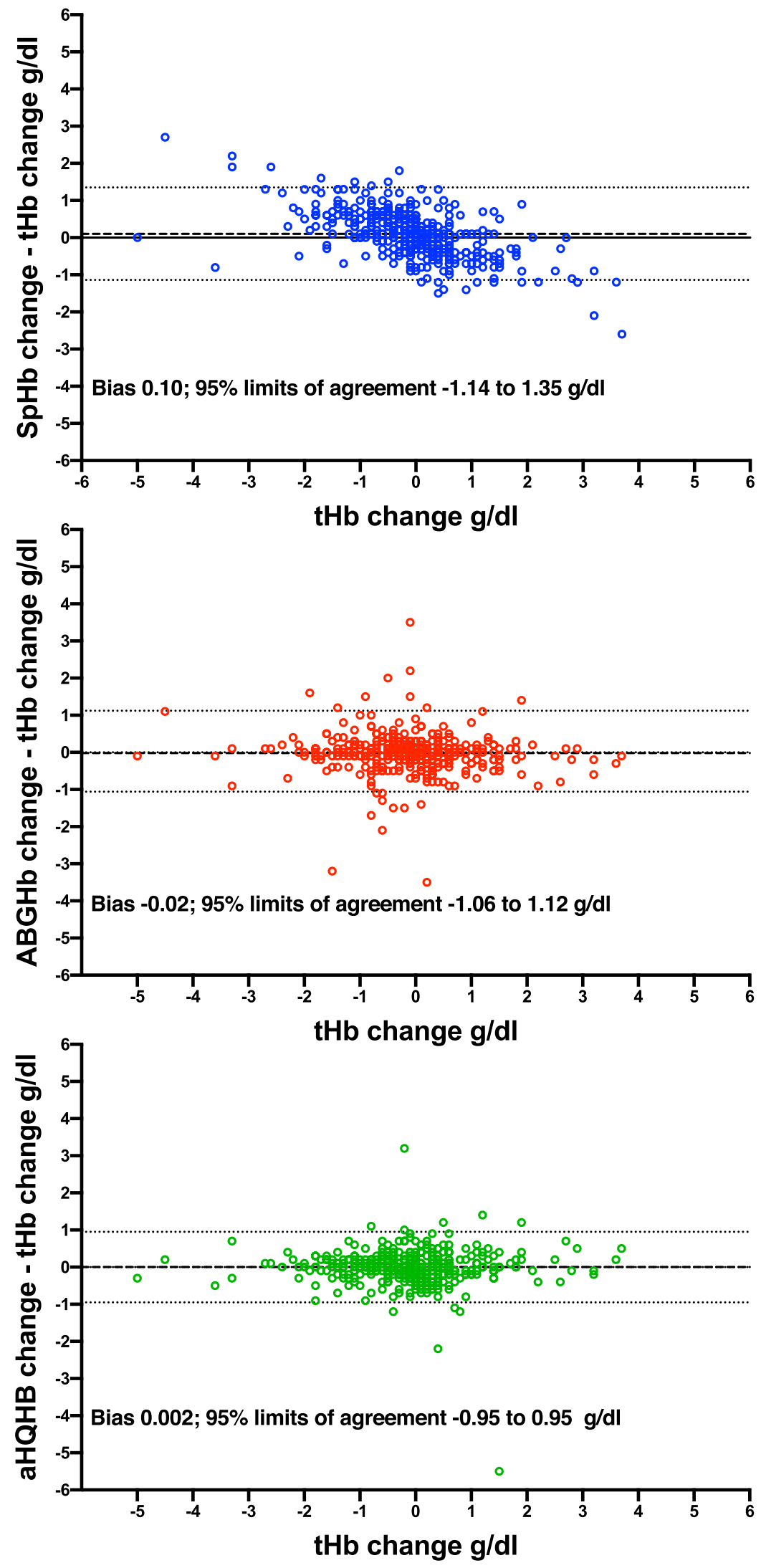
Fig. 2 Clinical acceptability plot of absolute accuracy comparing hemoglobin determined by laboratory hematology analyzer ( $\mathrm{tHb}$ ) to hemoglobin determined by top panel: pulse cooximetry ( $\mathrm{SpHb})$; middle panel: arterial blood gas cooximetry (ABGHb) and bottom panel: Hemocue point of care using arterial blood (aHQHb). Compared to results for $\mathrm{tHb}$ : zone A indicates results within a clinically acceptable range $( \pm 10 \%)$ at lower $\mathrm{tHb}$; zone $B$ indicates results that could represent a clinically significant error; and zone $\mathrm{C}$ indicates a potentially dangerous error in results from $\mathrm{SpHb}, \mathrm{ABGHb}$ or aHQHb [12, 13]
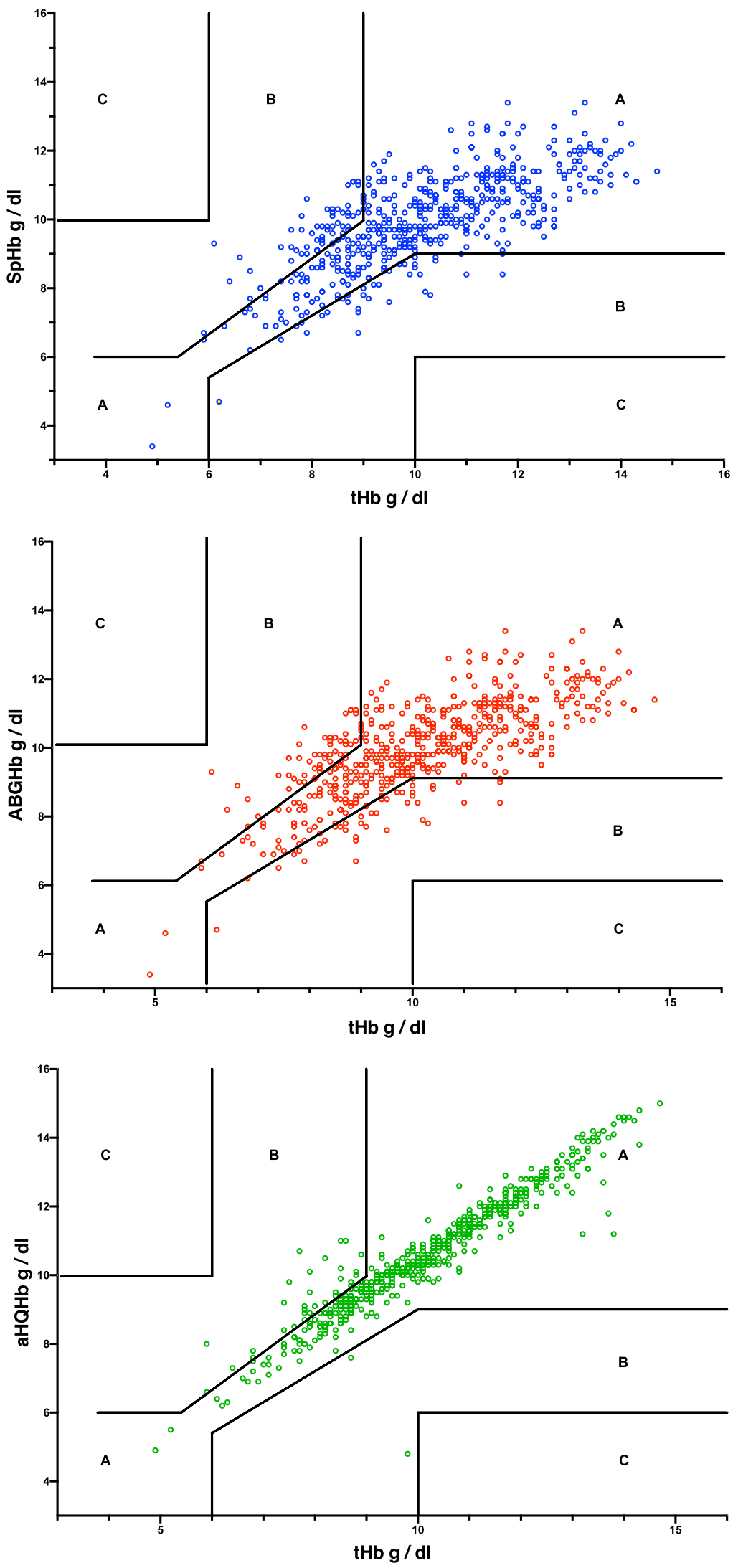
Table 2 Agreement of trend direction between $\mathrm{tHb}$ change more than $\pm 0.25 \mathrm{~g} / \mathrm{dl}$ and $\mathrm{SpHb}, \mathrm{ABGHb}$ and $\mathrm{aHQHb}$ change more than $\pm 0.5 \mathrm{~g} / \mathrm{dl}$

\begin{tabular}{cll}
\hline & $\begin{array}{l}\text { Same direction as tHb trend } \\
\mathrm{N}(\% ; 95 \% \mathrm{CI})\end{array}$ & $\begin{array}{l}\text { Not the same direc- } \\
\text { tion as tHb trend } \\
\mathrm{N}(\% ; 95 \% \mathrm{CI})\end{array}$ \\
\hline Increase & & \\
$\mathrm{SpHb}$ & $61(92.4 \% ; 83.5-96.7 \%)$ & $5(7.6 \% ; 3.3-16.5 \%)$ \\
$\mathrm{ABGHb}$ & $76(97.4 \% ; 91.1-99.3 \%)$ & $2(2.6 \% ; 0.7-8.9 \%)$ \\
$\mathrm{aHQHb}$ & $84(100 \% ; 95.6-100 \%)$ & 0 \\
Decrease & & \\
$\mathrm{SpHb}$ & $68(97.8 \% ; 88.3-98.6 \%)$ & $3(4.2 \% ; 1.4-11.7 \%)$ \\
$\mathrm{ABGHb}$ & $103(100 \% ; 96.4-100 \%)$ & 0 \\
$\mathrm{aHQHb}$ & $111(98.2 \% ; 93.8-99.5 \%)$ & $2(1.8 \% ; 0.5-6.2 \%)$ \\
\hline
\end{tabular}

education regarding the exclusion zone appropriate to clinical use of any $\mathrm{Hb}$ monitor. This exclusion zone could be different in other centers or when using varying analyzers.

The $\mathrm{SpHb}$ results can be compared to prior reports of single center studies. A study of volunteers found $95.4 \% \mathrm{SpHb}$ change agreement in 22 samples with $\mathrm{tHb}<10.0 \mathrm{~g} / \mathrm{dl}$ [15], which is similar to what we found. Using venous blood samples, a study of 70 trauma patients reported similar bias with narrower limits of agreement $(-0.05 ;-0.62$ to $0.51 \mathrm{~g} / \mathrm{dl})$ of $\mathrm{SpHb}$ change to tHb change than we report [16]. The number of patients and change calculations is smaller than included herein and reasons for the narrower limits of agreement are not clear, but may be partially explained by the multicenter source of our data. Studies of 48 vascular surgery patients

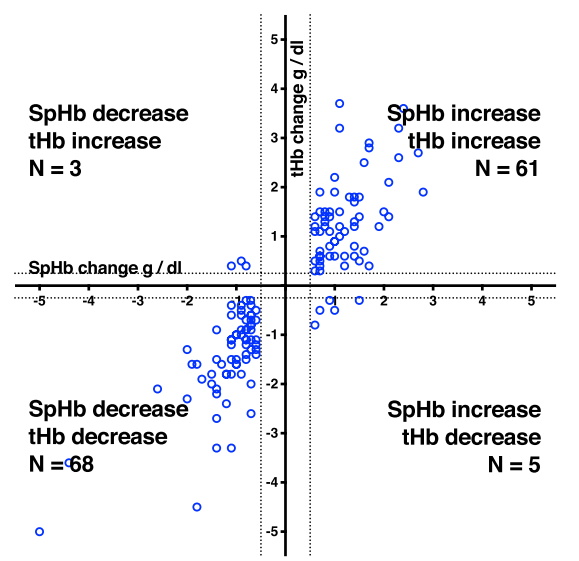

Fig. 3 Four quadrant plots of changes in laboratory hemoglobin (tHb) compared to changes in hemoglobin determined by left panel: pulse cooximetry $(\mathrm{SpHb})$; middle panel: arterial blood gas cooximetry $(\mathrm{ABGHb})$ and right panel: point of care device using arterial blood

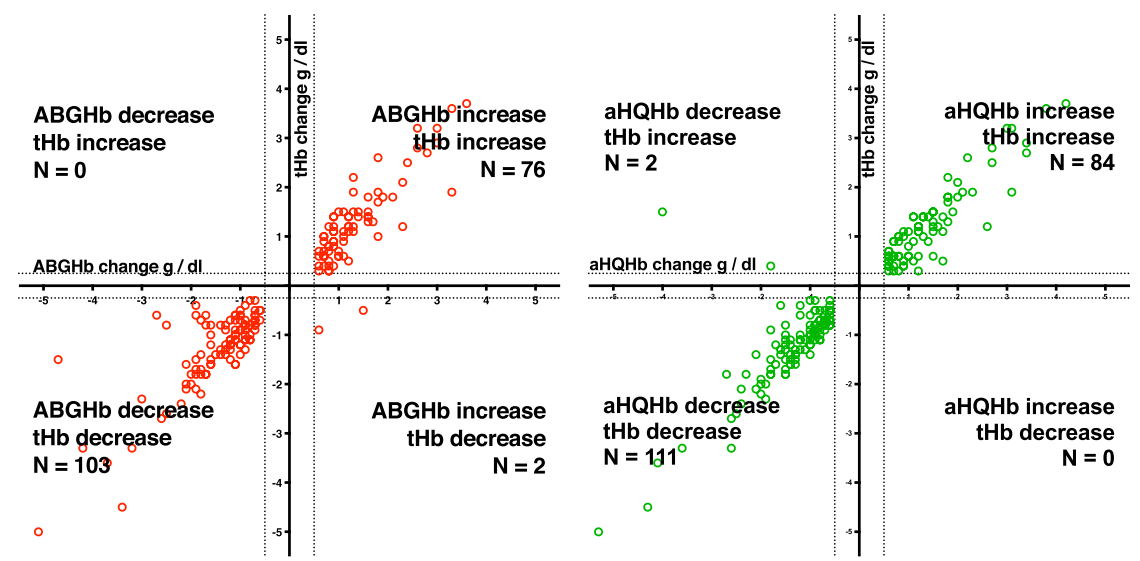

$(\mathrm{aHQHb})$. Dotted lines show limits of exclusion zones of $\pm 0.5 \mathrm{~g} /$ dl for $\mathrm{SpHb}, \mathrm{ABGHb}$ and $\mathrm{aHQHb}$ and $\pm 0.25 \mathrm{~g} / \mathrm{dl}$ for $\mathrm{tHb}$ based on repeated analysis of blood samples

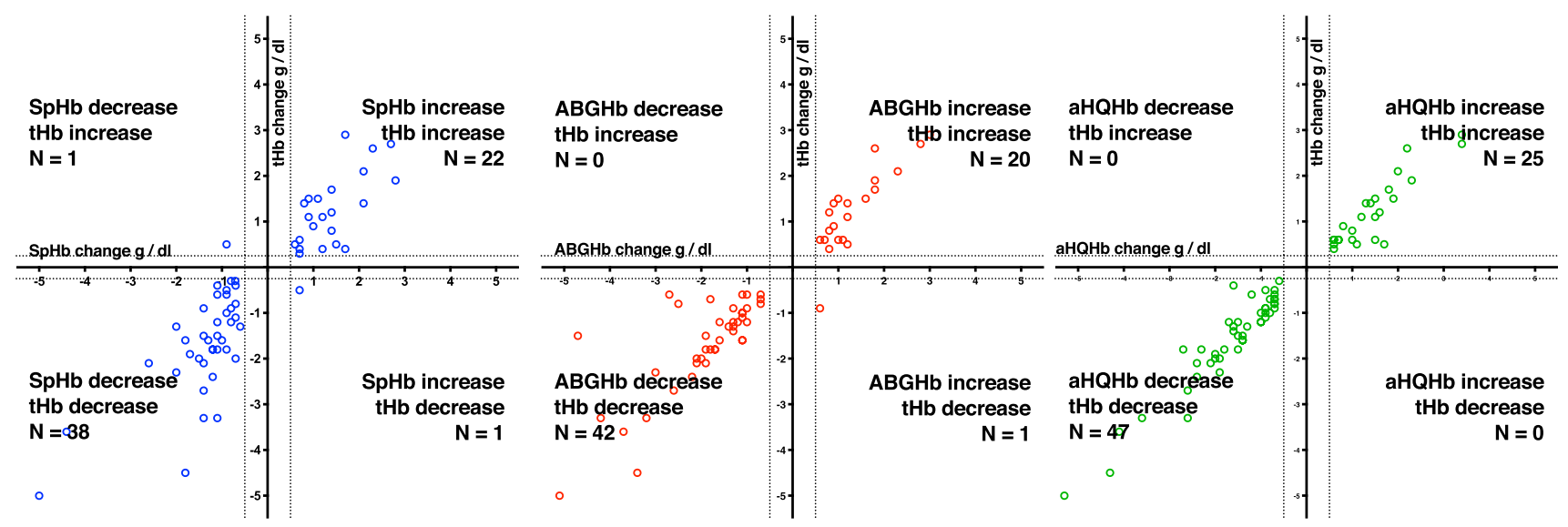

Fig. 4 Four quadrant plots of changes in laboratory hemoglobin ( $\mathrm{tHb})$ when $\mathrm{tHb}<9.0 \mathrm{~g} / \mathrm{dl}$ compared to changes in hemoglobin determined by left panel: pulse cooximetry $(\mathrm{SpHb})$; middle panel: arterial blood gas cooximetry $(\mathrm{ABGHb})$ and right panel: point of care device using arterial blood (aHQHb). Dotted lines show limits of exclusion zones of $\pm 0.5 \mathrm{~g} / \mathrm{dl}$ for $\mathrm{SpHb}, \mathrm{ABGHb}$ and $\mathrm{aHQHb}$ and $\pm 0.25 \mathrm{~g} / \mathrm{dl}$ for $\mathrm{tHb}$ based on repeated analysis of blood samples 
[17] and of 70 patients undergoing major orthopedic surgery [18] concluded $\mathrm{SpHb}$ had clinically acceptable trending with $\mathrm{ABGHb}$ or tHb. In 49 patients undergoing spine surgery, change concordance was $85.1 \%$ when excluding $\mathrm{SpHb}$ with perfusion index under 1 [19]. When using the exclusion zones determined by measurement repeatability analysis but not excluding $\mathrm{SpHb}$ based on low perfusion index, $\mathrm{SpHb}$ concordance was $94.2 \%$. Our findings are also better than reported in 69 patients undergoing spine or cancer surgery that employed a $1 \mathrm{~g} / \mathrm{dl}$ exclusion zone [20]. A study of patients undergoing abdominal or pelvic surgery found 41 of 269 changes at any $\mathrm{Hb}$ had increased $\mathrm{SpHb}$ when ABGHb decreased, including 14 in which the decrease was more than $-1 \mathrm{~g} / \mathrm{dl}$ [11]. Our finding of better trend direction agreement may be related to use of a newer $\mathrm{SpHb}$ version in the present study. We also found that $\mathrm{Hb}$ accuracy is improved compared to reports using earlier versions of the SpHb monitor [6-8, 11].

Study limitations include having only about $10 \%$ of change samples with $\mathrm{tHb} \leq 8.0 \mathrm{~g} / \mathrm{dl}$ (43 of 416$)$, which impacts our ability to assess clinical utility at very low tHb. However, change direction agreement was good for $\mathrm{tHb}<9.0 \mathrm{~g} / \mathrm{dl}$. The number of samples in which $\mathrm{SpHb}$, $\mathrm{ABGHb}$ or $\mathrm{aHQHb}$ change were not more than $\pm 0.5 \mathrm{~g} / \mathrm{dl}$ represents a potentially problematic grey zone for assessing $\mathrm{Hb}$ change. Although at $\mathrm{tHb}<9.0 \mathrm{~g} / \mathrm{dl}$ only $1 \mathrm{ABGHb}$ and $3 \mathrm{SpHb}$ decreases in this grey zone had associated $\mathrm{tHb}$ changes more than $-1.0 \mathrm{~g} / \mathrm{dl}$, potential clinical impact of these is not clear and could be evaluated in a future prospective study. We studied SpHb Rev K but newer SpHb versions could potentially have different or better trend accuracy. This could be assessed in a future study. The use of arterial blood can be seen as problematic for generalization to clinical settings in which venous or capillary blood is more commonly sampled. We used arterial blood samples as we studied patients at risk for blood loss and routinely use arterial catheters in such patients to facilitate care and blood sampling. Although venous blood may be easier to obtain in some clinical situations, setting $\mathrm{SpHb}$ monitors to arterial mode and using only arterial blood removed potential confounding that a mix of arterial and venous blood samples could have introduced into trend accuracy analyses. Differences between arterial and venous $\mathrm{Hb}$ have been reported as $0.2-0.3 \mathrm{~g} / \mathrm{dl}$ [21-23]. We would expect trend calculations to be similar to our findings if only venous blood samples were tested. Use of arterial blood samples to determine $\mathrm{aHQHb}$ likely provides different results compared to capillary finger stick blood samples. However, our patients had as many as 13 samples which would have required many finger or ear lobe punctures to allow comparison to capillary samples, thus we chose to use arterial blood samples. Compared to our results, wider limits of agreement between $\mathrm{tHb}$ and point of care $\mathrm{Hb}$ have been reported when using capillary finger or toe stick samples in patients undergoing cesarean section [24], with gastrointestinal bleeding [25], or in the emergency room [26] and correlated poorly to arterial and venous $\mathrm{tHb}$ in intensive care patients [27]. Finally, we did not ascertain whether blood loss was suspected by clinical conditions but the range of tHb change in sequential samples was -5.0 to $+3.7 \mathrm{~g} / \mathrm{dl}$, which reflects blood loss as well as transfusion decisions made by the anesthesiologists caring for the patients.

$\mathrm{Hb}$ measurement is essential to making patient centered transfusion decisions [28] which should improve outcomes [29] and reduce transfusion requirements [30-32]. Hb measurement is particularly important when blood loss is not obvious or is difficult to estimate during surgery as blood sampling to determine $\mathrm{tHb}$ can lag clinical situations. Surgical patients are reported to receive both unnecessary or excessive transfusion $[33,34]$ and anemia and transfusion can increase perioperative morbidity and mortality [35-37] for most but not all patients [38, 39]. However, postoperative outcome is reportedly better using less restrictive transfusion practices following some types of surgery [40], in elderly patients $[41,42]$ or in patients with cardiovascular disease $[43,44]$.

\subsection{Conclusions}

We found that $\mathrm{SpHb}, \mathrm{ABGHb}$ and $\mathrm{aHQHb}$ changes more than $\pm 0.5 \mathrm{~g} / \mathrm{dl}$ have similar correlation to the direction but not necessarily the magnitude of tHb change during surgery. The similar agreement in trend direction suggests that clinicians can choose which to use based on availability or preference, although continuous $\mathrm{SpHb}$ monitoring may provide useful ongoing $\mathrm{Hb}$ trend information. Continuous noninvasive $\mathrm{SpHb}$ decreases exceeding $-0.5 \mathrm{~g} / \mathrm{dl}$ may prompt a decision to obtain a confirmatory tHb measurement if low tHb is clinically suspected, but not replace blood $\mathrm{Hb}$ measurement in guiding transfusion decision making. Importantly, this study did not evaluate the transfusion impact of using these monitors so the transfusion impact of continuous noninvasive $\mathrm{Hb}$ monitoring needs to be studied prospectively.

Acknowledgements The authors acknowledge the assistance of Tristan Grogan MS, Principal Statistician, Division of General Internal Medicine and Health Services Research, University of California Los Angeles, and the research assistance of Gerald D. Andrews MBBS and Michael-David Calderon, BS.

Author contributions RLAII, MD helped design the study, conduct the study, analyze the data, and write the manuscript. PMA, MD helped analyze the data and write the manuscript. MC, MD PhD helped design the study, conduct the study, analyze the data, and write the manuscript. PP, MD helped conduct the study and write the manuscript. BLL, MD MPH helped conduct the study and write the manuscript. KT, MD 
helped design the study, conduct the study, analyze the data, and write the manuscript.

Funding Funding and material support for this study was provided by grants from Masimo Corporation to the Anesthesiology Departments at Loma Linda University School of Medicine (RA), Mayo Clinic in Florida (KT) and the University of California Irvine (MC) where the work was performed. The study protocol, conduct, analysis and write up were all under the control of the investigators.

\section{Compliance with ethical standards}

Conflicts of interest PP, BL, and PMA have nothing to disclose. RLA, $\mathrm{MC}$ and $\mathrm{KT}$ disclose each has been principal investigator in studies for which the Departments of Anesthesiology at their institutions received funding from Masimo Corporation and have served as consultants to Masimo Corporation scientific advisory boards. Dr. Torp holds regular shares in Masimo in an amount of less than \$50,000. Dr. Cannesson is a consultant for Edwards Lifesciences and Masimo Corp, and has funded research from Edwards Lifesciences and Masimo Corp. $\mathrm{He}$ is also the founder of Sironis owns patents and receive royalties for closed loop hemodynamic management that have been licensed to Edwards Lifesciences. Dr. Cannesson's Department receives funding from the NIH (R01GM117622; R01 NR013012; U54HL119893; 1R01HL144692).

Open Access This article is distributed under the terms of the Creative Commons Attribution 4.0 International License (http://creativeco mmons.org/licenses/by/4.0/), which permits unrestricted use, distribution, and reproduction in any medium, provided you give appropriate credit to the original author(s) and the source, provide a link to the Creative Commons license, and indicate if changes were made.

\section{References}

1. Clevenger B, Mallett SV, Klein AA, Richards T. Patient blood management to reduce surgical risk. Br J Surg. 2015;102(11):1325-1337; discussion 1324. https://doi. org/10.1002/bjs. 9898 .

2. Carson JL, Guyatt G, Heddle NM, Grossman BJ, Cohn CS, Fung MK, Gernsheimer T, Holcomb JB, Kaplan LJ, Katz LM, Peterson N, Ramsey G, Rao SV, Roback JD, Shander A, Tobian AA. Clinical practice guidelines from the AABB: red blood cell transfusion thresholds and storage. JAMA. 2016;316(19):2025-35. https:// doi.org/10.1001/jama.2016.9185.

3. Meybohm P, Richards T, Isbister J, Hofmann A, Shander A, Goodnough LT, Munoz M, Gombotz H, Weber CF, Choorapoikayil S, Spahn DR, Zacharowski K. Patient blood management bundles to facilitate implementation. Transfus Med Rev. 2017;31(1):62-71. https://doi.org/10.1016/j.tmrv.2016.05.012.

4. Sadana D, Pratzer A, Scher LJ, Saag HS, Adler N, Volpicelli FM, Auron M, Frank SM. Promoting high-value practice by reducing unnecessary transfusions with a patient blood management program. JAMA Intern Med. 2018;178(1):116-22. https://doi. org/10.1001/jamainternmed.2017.6369.

5. Zwart A, van Assendelft OW, Bull BS, England JM, Lewis SM, Zijlstra WG. Recommendations for reference method for haemoglobinometry in human blood (ICSH standard 1995) and specifications for international haemiglobinocyanide standard (4th edition). J Clin Pathol 1996;49 (4):271-274. https://doi.org/10.1136/ jcp.49.4.271.
6. Macknet MR, Allard M, Applegate RL 2nd, Rook J. The accuracy of noninvasive and continuous total hemoglobin measurement by pulse CO-Oximetry in human subjects undergoing hemodilution. Anesth Analg. 2010;111(6):1424-6. https://doi.org/10.1213/ ANE.0b013e3181fc74b9.

7. Kim SH, Lilot M, Murphy LS, Sidhu KS, Yu Z, Rinehart J, Cannesson M. Accuracy of continuous noninvasive hemoglobin monitoring: a systematic review and meta-analysis. Anesth Analg. 2014;119(2):332-46. https://doi.org/10.1213/ANE.0000000000 000272.

8. Hiscock R, Kumar D, Simmons SW. Systematic review and metaanalysis of method comparison studies of Masimo pulse co-oximeters (Radical-7 or Pronto-7) and HemoCue(R) absorption spectrometers (B-Hemoglobin or 201+) with laboratory haemoglobin estimation. Anaesth Intensive Care. 2015;43(3):341-50. https:// doi.org/10.1177/0310057X1504300310.

9. American Society of Anesthesiologists Task Force on Perioperative Blood M. Practice guidelines for perioperative blood management: an updated report by the American Society of Anesthesiologists Task Force on Perioperative Blood Management. Anesthesiology. 2015;122(2):241-75. https://doi.org/10.1097/ ALN.0000000000000463.

10. American Society of Anesthesiologists Task Force on Perioperative Blood T, Adjuvant T. Practice guidelines for perioperative blood transfusion and adjuvant therapies: an updated report by the American Society of Anesthesiologists Task Force on Perioperative Blood Transfusion and Adjuvant Therapies. Anesthesiology. 2006;105(1):198-208. https://doi.org/10.1097/00000542-20060 7000-00030.

11. Applegate RL 2nd, Barr SJ, Collier CE, Rook JL, Mangus DB, Allard MW. Evaluation of pulse cooximetry in patients undergoing abdominal or pelvic surgery. Anesthesiology. 2012;116(1):6572. https://doi.org/10.1097/ALN.0b013e31823d774f.

12. Rice MJ, Gravenstein N, Morey TE. Noninvasive hemoglobin monitoring: how accurate is enough? Anesth Analg. 2013;117(4):902-7. https://doi.org/10.1213/ANE.0b013e3182 $9483 \mathrm{fb}$.

13. Morey TE, Gravenstein N, Rice MJ. Let's think clinically instead of mathematically about device accuracy. Anesth Analg. 2011;113(1):89-91. https://doi.org/10.1213/ANE.0b013e3182 $19 \mathrm{a} 290$.

14. Society of Thoracic Surgeons Blood Conservation Guideline Task F, Ferraris VA, Brown JR, Despotis GJ, Hammon JW, Reece TB, Saha SP, Song HK, Clough ER, Society of Cardiovascular Anesthesiologists Special Task Force on Blood T, Shore-Lesserson LJ, Goodnough LT, Mazer CD, Shander A, Stafford-Smith M, Waters J, International Consortium for Evidence Based P, Baker RA, Dickinson TA, FitzGerald DJ, Likosky DS, Shann KG. 2011 update to the Society of Thoracic Surgeons and the Society of Cardiovascular Anesthesiologists blood conservation clinical practice guidelines. Ann Thorac Surg. 2011;91(3):944-82. https ://doi.org/10.1016/j.athoracsur.2010.11.078.

15. Marques NR, Kramer GC, Voigt RB, Salter MG, Kinsky MP. Trending, accuracy, and precision of noninvasive hemoglobin monitoring during human hemorrhage and fixed crystalloid bolus. Shock. 2015;44(Suppl 1):45-9. https://doi.org/10.1097/ SHK.0000000000000310.

16. Gamal M, Abdelhamid B, Zakaria D, Dayem OAE, Rady A, Fawzy M, Hasanin A. Evaluation of noninvasive hemoglobin monitoring in trauma patients with low hemoglobin levels. Shock. 2018;49(2):150-3. https://doi.org/10.1097/SHK.0000000000 000949.

17. De Rosa RC, Romano GM, Abbate R, Corcione A, De Robertis E. Accuracy and trending ability of hemoglobin measurement by the Pulse CO-Oximeter during vascular surgery. J Clin Monit Comput. 2019. https://doi.org/10.1007/s10877-019-00337-5. 
18. Adel A, Awada W, Abdelhamid B, Omar H, Abd El Dayem O, Hasanin A, Rady A. Accuracy and trending of non-invasive hemoglobin measurement during different volume and perfusion statuses. J Clin Monit Comput. 2018;32(6):1025-31. https://doi. org/10.1007/s10877-018-0101-z.

19. Chang FC, Lin JR, Liu FC. Validity of accuracy and trending ability of non-invasive continuous total hemoglobin measurement in complex spine surgery: a prospective cohort study. BMC Anesthesiol. 2019;19(1):117. https://doi.org/10.1186/s12871-019-0790-y.

20. Tang B, Yu X, Xu L, Zhu A, Zhang Y, Huang Y. Continuous noninvasive hemoglobin monitoring estimates timing for detecting anemia better than clinicians: a randomized controlled trial. BMC Anesthesiol. 2019;19(1):80. https://doi.org/10.1186/s1287 1-019-0755-1.

21. Yang ZW, Yang SH, Chen L, Qu J, Zhu J, Tang Z. Comparison of blood counts in venous, fingertip and arterial blood and their measurement variation. Clin Lab Haematol. 2001;23(3):155-9. https://doi.org/10.1213/ANE.0000000000000927.

22. Evron S, Tress V, Ezri T, Szmuk P, Landau O, Hendel D, Schechter P, Medalion B. The importance of blood sampling site for determination of hemoglobin and biochemistry values in major abdominal and orthopedic surgery. J Clin Anesth. 2007;19(2):926. https://doi.org/10.1016/j.jclinane.2006.04.005.

23. Mokken FC, van der Waart FJ, Henny CP, Goedhart PT, Gelb AW. Differences in peripheral arterial and venous hemorheologic parameters. Ann Hematol. 1996;73(3):135-7. https://doi. org/10.1007/s002770050214.

24. Richards NA, Boyce H, Yentis SM. Estimation of blood haemoglobin concentration using the HemoCue during caesarean section: the effect of sampling site. Int J Obstet Anesth. 2010;19(1):67-70. https://doi.org/10.1016/j.ijoa.2009.05.010.

25. Van de Louw A, Lasserre N, Drouhin F, Thierry S, Lecuyer L, Caen D, Tenaillon A. Reliability of HemoCue in patients with gastrointestinal bleeding. Intensive Care Med. 2007;33(2):355-8. https://doi.org/10.1007/s00134-006-0461-6.

26. Zatloukal J, Pouska J, Kletecka J, Pradl R, Benes J. Comparison of the accuracy of hemoglobin point of care testing using HemoCue and GEM Premier 3000 with automated hematology analyzer in emergency room. J Clin Monit Comput. 2015. https:// doi.org/10.1007/s10877-015-9799-z.

27. Seguin P, Kleiber A, Chanavaz C, Morcet J, Malledant Y. Determination of capillary hemoglobin levels using the HemoCue system in intensive care patients. J Crit Care. 2011;26(4):423-7. https ://doi.org/10.1016/j.jcrc.2010.08.012.

28. Mueller MM, Van Remoortel H, Meybohm P, Aranko K, Aubron C, Burger R, Carson JL, Cichutek K, De Buck E, Devine D, Fergusson D, Follea G, French C, Frey KP, Gammon R, Levy JH, Murphy MF, Ozier Y, Pavenski K, So-Osman C, Tiberghien P, Volmink J, Waters JH, Wood EM, Seifried E, Group IPF. Patient blood management: recommendations from the 2018 Frankfurt consensus conference. JAMA. 2019;321(10):983-97. https://doi. org/10.1001/jama.2019.0554.

29. Zacharowski K, Spahn DR. Patient blood management equals patient safety. Best Pract Res Clin Anaesthesiol. 2016;30(2):15969. https://doi.org/10.1016/j.bpa.2016.04.008.

30. Butcher A, Richards T. Cornerstones of patient blood management in surgery. Transfus Med. 2018;28(2):150-7. https://doi. org/10.1111/tme.12476.

31. Chandra S, Kulkarni H, Westphal M. The bloody mess of red blood cell transfusion. Crit Care. 2017;21(Suppl 3):310. https:// doi.org/10.1186/s13054-017-1912-x.

32. Jenkins I, Doucet JJ, Clay B, Kopko P, Fipps D, Hemmen E, Paulson D. Transfusing wisely: clinical decision support improves blood transfusion practices. Jt Commun J Qual Patient Saf. 2017;43(8):389-95. https://doi.org/10.1016/j.jcjq.2017.04.003.
33. Callum JL, Waters JH, Shaz BH, Sloan SR, Murphy MF. The $\mathrm{AABB}$ recommendations for the choosing wisely campaign of the American Board of Internal Medicine. Transfusion. 2014;54(9):2344-52. https://doi.org/10.1111/trf.12802.

34. Dubost C, Ausset S, Vincent C, Gozlan C, Auroy Y, N'Guyen L, Lienhart A, Benhamou D. Hospital audit of delayed transfusion after orthopaedic surgery. Anaesth Crit Care Pain Med. 2015;34(6):321-5. https://doi.org/10.1016/j.accpm.2015.02.006.

35. Gabriel RA, Clark AI, Nguyen AP, Waterman RS, Schmidt UH. The association of preoperative hematocrit and transfusion with mortality in patients undergoing elective non-cardiac surgery. World J Surg. 2017. https://doi.org/10.1007/s00268-017-4359-y.

36. Baron DM, Hochrieser H, Posch M, Metnitz B, Rhodes A, Moreno RP, Pearse RM, Metnitz P, European Surgical Outcomes Study group for Trials Groups of European Society of Intensive Care M, European Society of A. Preoperative anaemia is associated with poor clinical outcome in non-cardiac surgery patients. $\mathrm{Br} \mathbf{J}$ Anaesth. 2014;113(3):416-23. https://doi.org/10.1093/bja/aeu09 8.

37. Fowler AJ, Ahmad T, Phull MK, Allard S, Gillies MA, Pearse RM. Meta-analysis of the association between preoperative anaemia and mortality after surgery. Br J Surg. 2015;102(11):1314-24. https://doi.org/10.1002/bjs.9861.

38. Saager L, Turan A, Reynolds LF, Dalton JE, Mascha EJ, Kurz A. The association between preoperative anemia and 30-day mortality and morbidity in noncardiac surgical patients. Anesth Analg. 2013;117(4):909-15. https://doi.org/10.1213/ANE.0b013e3182 $8 \mathrm{~b} 347 \mathrm{~d}$.

39. Tran L, Greiff G, Pleym H, Wahba A, Stenseth R, Videm V. Transfusion of red blood cells in coronary surgery: is there an effect on long-term mortality when adjusting for risk factors and postoperative complications? Eur J Cardiothorac Surg. 2017. https://doi. org/10.1093/ejcts/ezx431.

40. Gu WJ, Gu XP, Wu XD, Chen H, Kwong JSW, Zhou LY, Chen S, Ma ZL. Restrictive versus liberal strategy for red blood-cell transfusion: a systematic review and meta-analysis in orthopaedic patients. J Bone Jt Surg Am. 2018;100(8):686-95. https://doi. org/10.2106/JBJS.17.00375.

41. Simon GI, Craswell A, Thom O, Fung YL. Outcomes of restrictive versus liberal transfusion strategies in older adults from nine randomised controlled trials: a systematic review and meta-analysis. Lancet Haematol. 2017;4(10):e465-74. https://doi.org/10.1016/ S2352-3026(17)30141-2.

42. Hovaguimian F, Myles PS. Restrictive versus liberal transfusion strategy in the perioperative and acute care settings: a contextspecific systematic review and meta-analysis of randomized controlled trials. Anesthesiology. 2016;125(1):46-61. https://doi. org/10.1097/ALN.0000000000001162.

43. Cortes-Puch I, Wiley BM, Sun J, Klein HG, Welsh J, Danner RL, Eichacker PQ, Natanson C. Risks of restrictive red blood cell transfusion strategies in patients with cardiovascular disease (CVD): a meta-analysis. Transfus Med. 2018;28(5):335-45. https ://doi.org/10.1111/tme.12535.

44. Docherty AB, O’Donnell R, Brunskill S, Trivella M, Doree C, Holst L, Parker M, Gregersen M, Pinheiro de Almeida J, Walsh TS, Stanworth SJ. Effect of restrictive versus liberal transfusion strategies on outcomes in patients with cardiovascular disease in a non-cardiac surgery setting: systematic review and meta-analysis. BMJ. 2016;352:i1351. https://doi.org/10.1136/bmj.i1351.

Publisher's Note Springer Nature remains neutral with regard to jurisdictional claims in published maps and institutional affiliations. 